\title{
Turunan (Derivatif): Sebuah Pendekatan Matematis dalam Analisis Keuntungan Maksimum
}

\author{
Nurwahidah \\ Universitas Islam Negeri Alauddin Makassar, nurwahidah.abidin@uin-alauddin.ac.id \\ Andi Mariani \\ Universitas Islam Negeri Alauddin Makassar, andi.marianidatu@gmail.com
}

\begin{abstract}
ABSTRAK, Penelitian ini membahas tentang analisis keuntungan maksimum yang dilakukan pada Kedai Ana, sebuah usaha rumahan di Kota Makassar yang baru dirintis. Hasil observasi yang dilakukan pada Kedai Ana memberikan gambaran bahwa pemilik kedai masih kesulitan untuk memperoleh keuntungan maksimum yang ditandai dengan adanya perubahan harga penjualan untuk beberapa menu yang ditawarkan. Turunan (derivatif) merupakan pendekatan matematis yang digunakan untuk melakukan analisis keuntungan maksimum. Penelitian ini bertujuan untuk menganalisis tingkat keuntungan maksimum yang dihasilkan oleh suatu usaha menggunakan konsep turunan. Hasil analisis menyatakan bahwa Kedai Ana belum mencapai keuntungan maksimum yang ditunjukkan dengan tidak semua menu yang ditawarkan memiliki hasil turunan kedua yang bernilai negatif.
\end{abstract}

Kata Kunci: derivatif, keuntungan maksimum, turunan

\section{PENDAHULUAN}

Matematika sering disebut sebagai queen of science. Baik disadari maupun tidak, setiap aktifitas dalam kehidupan selalu memiliki hubungan dengan matematika. Teknologi yang dibuat untuk memudahkan kehidupan manusia dan ilmu pengetahuan lain selalu berlandaskan pada ilmu matematika. Dengan demikian, matematika memiliki sangat banyak terapan dalam kehidupan sehari-hari.

Matematika memiliki andil yang sangat besar dalam bidang ekonomi. Sebuah konsep dalam matematika dapat memiliki beberapa terapan dalam bidang ekonomi. Matematika berperan sebagai sebuah pendekatan dalam melakukan analisis ekonomi.

Turunan derivatif merupakan salah satu konsep dalam matematika yang memiliki banyak aplikasi dalam bidang ekonomi. Beberapa penerapan fungsi turunan dalam mikro ekonomi diantaranya adalah perhitungan biaya marginal, penerimaan marginal, dan produk marginal. Selain itu, turunan juga dapat digunakan untuk menghitung manfaat tambahan dari konsumen karena peningkatan satu unit barang yang dikonsumsi atau kegunaan marginal. Penerapan konsep turunan fungsi yang tak kalah penting dalam bidang ekonomi adalah dalam analisis keuntungan maksimum.

Keuntungan merupakan motivasi pelaku produksi dalam berkegiatan ekonomi. Akan tetapi, masalah yang terkait dengan perolehan keuntungan sering dialami oleh usaha yang baru dirintis. Observasi yang dilakukan pada usaha rumahan yang baru dirintis dalam hal ini Kedai Ana memberikan gambaran bahwa pemilik kedai masih kesulitan untuk memperoleh keuntungan maksimum. Selain itu, pemilik kedai juga masih memiliki kendala dalam menentukan target penjualan dan harga yang tepat untuk setiap menu yang ditawarkan. Berdasarkan data yang diperoleh, setiap menu dijual dengan harga Rp5000,00 pada bulan November 2020. Sebulan kemudian sudah terdapat perbedaan harga pada setiap menu yang ditawarkan. Hasil wawancara dengan pemilik kedai dinyatakan bahwa adanya perubahan harga pada menu yang ditawarkan diakibatkan karena pemilik belum memperoleh keuntungan yang maksimal.

Berdasarkan masalah yang dialami oleh pemilik Kedai Ana dalam mencapai tingkat keuntungan maksimum, maka dibutuhkan sebuah analisis agar diperoleh efisiensi ekonomi berupa tingkat keuntungan yang optimal. Analisis keuntungan maksimum dilakukan dengan menerapkan konsep turunan derivatif. Turunan pertama dan kedua sebuah fungsi keuntungan dapat digunakan untuk menganalisis keuntungan maksimum. Penerapan konsep turunan pada analisis keuntungan maksimum suatu usaha dapat digunakan oleh pemilik usaha untuk memprediksi laba yang akan diperoleh [1]. Dengan kata lain, analisis keuntungan merupakan analisis teoritik yang dapat menjadi jalan keluar dari masalah perolehan keuntungan 
suatu usaha dan dapat dijadikan sebagai pedoman pengembangan sebuah usaha [2].

Analisis keuntungan maksimum dapat dilakukan dengan berbagai macam pendekatan. M.S. Rumetna, dkk [3] menggunakan metode simpleks dalam menghitung keuntungan maksimal dari penjualan roti abon gulung. Penelitian yang dilakukukan M.S. Rumetna melibatkan software POM-QM dalam proses analisis data. Z. Nasution, dkk [4] mengembangkan sebuah alat bantu untuk melakukan analisis keuntungan maksimum menggunakan pendekatan persamaan linear.

Dalam menjalankan sebuah usaha, keuntungan selalu menduduki peranan penting dan mendapat perhatian khusus dari pelaku usaha. Penelitian ini bertujuan untuk menganalisis tingkat keuntungan maksimum yang dihasilkan oleh suatu usaha menggunakan konsep turunan. Penelitian ini diharapkan dapat menjadi bahan pertimbangan bagi pemilik usaha khususnya Kedai Ana untuk menentukan harga dan target penjualan agar tercapai keuntungan maksimum.

\section{TINJAUAN PUSTAKA}

\section{Definisi Derivatif Fungsi}

Derivatif fungsi $f$ merupakan fungsi berbeda $f^{\prime}$ dengan nilai pada sebarang bilangan $c$ adalah

$$
f^{\prime}=\lim _{h \rightarrow 0} \frac{f(c+h)-f(x)}{h}
$$

jika mempunyai limit [5].

Apabila fungsi di atas memiliki limit atau limitnya ada, maka fungsi $f$ dapat dideferensialkan dan $f^{\prime}$ merupakan derivatif atau turunan pertama. Lebih lanjut lagi, jika derivatif pertama dari fungsi $f^{\prime}$ ada, maka derivatif ini disebut sebagai derivatif kedua dari $f$ dan dituliskan sebagai $f^{\prime \prime}$.

\section{Definisi Maksimum dan Minimum}

Misalkan $S$ merupakan daerah asal $f$ memuat titik $c$, maka:

i. $f(c)$ adalah nilai maksimum $f$ di $S$ jika $f(c) \geq f(x), \forall x \in S$. ii. $f(c)$ adalah nilai minimum $f$ di $S$ jika $f(c) \leq f(x), \forall x \in S$.

iii. $f(c)$ adalah nilai ekstrim $f$ di $S$ jika $f(c)$ merupakan nilai maksimum atau minimum [5].

\section{Uji Derivatif Pertama dan Kedua}

Penentuan nilai maksimum dan minimum dapat menggunakan uji derivatif pertama dan kedua sebagai berikut [6]:

a. Uji Derivatif Pertama

Misalkan fungsi $f$ kontinu pada selang terbuka $(a, b)$ yang memuat sebuah titik kritis $c$.

i. Jika fungsi $f^{\prime}(x)>0$ untuk setiap $x$ dalam $(a, c)$ dan $f^{\prime}(x)<0$ untuk setiap $x$ dalam $(c, b)$, maka $x$ dalam $f(c)$ merupakan nilai maksimum lokal $f$.

ii. Jika fungsi $f^{\prime}(x)<0$ untuk setiap $x$ dalam $(a, c)$ dan $f^{\prime}(x)>0$ untuk setiap $x$ dalam $(c, b)$, maka $x$ dalam $f(c)$ merupakan nilai minimum lokal $f$.

iii. Jika $f^{\prime}(x)$ memiliki tanda sama pada semua pihak $c$, maka $f(c)$ bukan nilai ekstrim lokal $f$.

\section{b. Uji Derivatif Kedua}

Misalkan fungsi $f^{\prime}$ dan $f^{\prime \prime}$ ada pada setiap titik dalam selang terbuka $(a, b)$ yang memuat $c$ dan $f^{\prime}(c)=0$.

i. Jika fungsi $f^{\prime}(x)<0$, maka $f(c)$ merupakan nilai maksimum lokal $f$.

ii. Jika fungsi $f^{\prime}(x)>0$, maka $f(c)$ merupakan nilai minimum lokal $f$.

\section{METODOLOGI}

Penelitian yang dilakukan menggunakan metode studi kasus. Pengambilan data dilakukan di Kedai Ana, Jalan Manuruki II, Kota Makassar, Sulawesi Selatan. Data yang digunakan dalam penelitian ini adalah data yang menyangkut biaya operasional rutin bulanan, proses produksi, dan penjualan bulanan dari setiap menu yang tersedia di Kedai Ana.

Pengumpulan data, tabulasi data, dan perhitungan menggunakan konsep turunan 
derivatif merupakan tahapan yang dilakukan dalam penelitian ini.

\section{Prosedur Penelitian}

Langkah-langkah dalam menentukan keutungan maksimum dapat dijelaskan sebagai berikut:

1. Menentukan fungsi biaya (C).

Fungsi biaya dapat dinyatakan sebagai berikut:

$$
C=T F C+T V C
$$

dengan:

TFC = Total Fixed Cost (biaya tetap total)

$T V C=$ Total Variable Cost (biaya variabel total)

2. Menentukan fungsi permintaan (P).

Fungsi permintaan dapat dituliskan sebagai berikut:

dengan:

$$
Q d=-a P+b
$$

$Q d=$ Quantity demand (jumlah permintaan)

$P=$ harga

$a, b=$ konstanta

Fungsi permintaan juga dapat dicari dengan formula sebagai berikut:

$$
\frac{P-P_{1}}{P_{2}-P_{1}}=\frac{Q-Q_{1}}{Q_{2}-Q_{1}}
$$

dengan:

$P_{1}, P_{2}=$ harga pada periode 1 dan 2

$Q_{1}, Q_{2}=$ jumlah barang pada periode 1 dan 2

3. Menetukan fungsi penerimaan (R).

Penerimaan produsen dari hasil penjualan produksi dapat dinyatakan sebagai berikut:

$$
R=P \cdot Q
$$

4. Menentukan fungsi keuntungan $(\pi)$.

Fungsi keuntungan merupakan selisih dari fungsi penerimaan dan fungsi biaya yang dapat dinyatakan sebagai berikut:

$$
\pi=R-C
$$

5. Menentukan keuntungan maksimum dengan mencari titik ekstrim dari perhitungan turunan pertama fungsi keuntungan yang disamadengankan 0 .

6. Menentukan titik maksimum atau minimum dari titik esktrim yang ada. Hal ini dilakukan dengan mencari turunan kedua dari fungsi keuntungan yang disamadengankan 0. Jika setelah substitusi titik ekstrim ke turunan kedua fungsi bernilai negatif, maka titik ekstrim yang disubstitusikan merupakan titik maksimum. Sebaliknya, jika setelah substitusi titik ekstrim ke turunan kedua fungsi bernilai positif, maka titik ekstrim yang disubstitusikan merupakan titik minimum.

\section{PEMBAHASAN}

\section{Profil Data}

Berdasarkan hasil pengumpulan data, data yang diperoleh disajikan dalam tabel sebagai berikut:

Tabel 4.1 Biaya Operasional Rutin Bulanan

\begin{tabular}{ccc}
\hline No. & Uraian & Jumlah \\
\hline 1 & Listrik & 50.000 \\
2 & Air Galon & 30.000 \\
\hline & Jumlah & $\mathbf{8 0 . 0 0 0}$ \\
\hline
\end{tabular}

Berdasarkan Tabel 4.1, biaya operasional rutin bulanan hanya terdiri dari biaya listrik dan air galon. Biaya yang terkait dengan sewa tempat dan gaji karyawan tidak diperhitungkan berhubung usaha Kedai Ana masih berupa usaha rumahan yang hanya dikelola oleh 1 orang.

Kedai Ana menyediakan 2 jenis minuman, yakni: Thai tea dan Kopi susu. Biaya produksi untuk setiap jenis minuman adalah sebesar Rp 2500,00 per porsi. Selain menyediakan minuman, Kedai Ana juga menyediakan 3 jenis cemilan berupa lumpia telur, cilok dan gorengan dengan biaya produksi Rp 3000,00 per porsi.

Tabel 4.2 Penjualan Bulan November 2020

\begin{tabular}{clcc}
\hline No. & \multicolumn{1}{c}{ Menu } & $\begin{array}{c}\text { Harga } \\
\text { Jual }\end{array}$ & $\begin{array}{c}\text { Jumlah } \\
\text { Penjualan }\end{array}$ \\
\hline 1 & Thai tea & 5000 & 30 \\
2 & Kopi susu & 5000 & 40 \\
3 & Lumpia telur & 5000 & 65 \\
4 & Cilok & 5000 & 100 \\
5 & Gorengan & 5000 & 50 \\
\hline \multicolumn{2}{c}{ Jumlah } & $\mathbf{2 8 5}$ \\
\hline
\end{tabular}

Tabel 4.3 Penjualan Bulan Desember 2020

\begin{tabular}{clcc}
\hline No. & Menu & $\begin{array}{c}\text { Harga } \\
\text { Jual }\end{array}$ & $\begin{array}{c}\text { Jumlah } \\
\text { Penjualan }\end{array}$ \\
\hline 1 & Thai tea & 7000 & 25 \\
2 & Kopi susu & 7000 & 45 \\
\hline
\end{tabular}




\begin{tabular}{clcc}
\hline No. & \multicolumn{1}{c}{ Menu } & $\begin{array}{c}\text { Harga } \\
\text { Jual }\end{array}$ & $\begin{array}{c}\text { Jumlah } \\
\text { Penjualan }\end{array}$ \\
\hline 3 & Lumpia telur & 6000 & 75 \\
4 & Cilok & 6000 & 85 \\
5 & Gorengan & 7000 & 30 \\
\hline \multicolumn{3}{c}{ Jumlah } & $\mathbf{2 6 0}$ \\
\hline
\end{tabular}

\section{Analisis Keuntungan Maksimum}

Berdasarkan data yang diperoleh, maka dapat dibuat analisis keuntungan maksimum dari setiap menu sebagai berikut:

a. Analisis keuntungan menu Thai tea

Fungsi biaya (C) untuk menu Thai tea dapat disusun berdasarkan biaya operasional rutin bulanan dan biaya produksi untuk menu Thai tea.

$$
C=80000+2500 Q
$$

Fungsi harga $(\mathrm{P})$ untuk menu Thai tea dapat dituliskan sebagai berikut:

$$
P=-400 Q+17000
$$

Dengan demikian, diperoleh fungsi penerimaan sebagai berikut:

$$
R=-400 Q^{2}+17000 Q
$$

Berdasarkan fungsi penerimaan dan fungsi biaya, fungsi keuntungan dapat dituliskan sebagai berikut:

$\pi=-400 Q^{2}+14500 Q-80000$

Koefisien pada variabel kuadrat fungsi keuntungan bernilai negatif. Hal ini menunjukkan bahwa grafik parabola akan terbuka ke bawah yang berarti keuntungan maksimum dicapai ketika jumlah penjualan bernilai sama dengan titik kritis.

Derivatif pertama fungsi keuntungan yang disamadengankan 0 menghasilkan titik kritis sebesar 18,125. Hal ini berarti Kedai Ana melakukan penjualan Thai tea sebanyak 18 porsi dalam jangka waktu sebulan.

Penentuan titik ektrim maksimum atau minimum dilakukan dengan mencari turunan kedua dari fungsi keuntungan. Pada proses ini, diperoleh hasil -800. Hasil derivatif kedua yang lebih kecil dari 0 menunjukkan bahwa titik tersebut merupakan titik maksimum. Sehingga dapat dinyatakan bahwa Kedai Ana memperoleh keuntungan maksimum sebesar Rp51.400,00 jika tingkat penjualan Thai tea sebanyak 18 porsi dalam waktu sebulan. Dengan demikian, harga minimal Thai tea yang perlu ditetapkan oleh Kedai Ana untuk memperoleh keuntungan adalah sebesar Rp9.800,00 per porsi.

b. Analisis keuntungan menu kopi susu

Fungsi biaya (C) untuk menu kopi susu dapat disusun berdasarkan biaya operasional rutin bulanan dan biaya produksi untuk menu kopi susu.

$$
C=80000+2500 Q
$$

Fungsi harga (P) untuk menu kopi susu dapat dituliskan sebagai berikut:

$$
P=400 Q-7000
$$

Dengan demikian, diperoleh fungsi penerimaan sebagai berikut:

$$
R=400 Q^{2}-7000 Q
$$

Berdasarkan fungsi penerimaan dan fungsi biaya, fungsi keuntungan dapat dituliskan sebagai berikut:

$\pi=400 Q^{2}-9500 Q-80000$

Derivatif pertama fungsi keuntungan yang disamadengankan 0 menghasilkan titik kritis sebesar 11,875. Hal ini berarti Kedai Ana melakukan penjualan kopi susu sebanyak 12 porsi dalam jangka waktu sebulan.

Penentuan titik ektrim maksimum atau minimum dilakukan dengan mencari turunan kedua dari fungsi keuntungan. Pada proses ini, diperoleh hasil 800. Hasil derivatif kedua yang lebih besar dari 0 menunjukkan bahwa titik tersebut merupakan titik minimum. Sehingga dapat dinyatakan bahwa Kedai Ana memperoleh kerugian maksimum sebesar Rp-136.400,00 jika tingkat penjualan kopi susu sebanyak 12 porsi dalam waktu sebulan.

c. Analisis keuntungan menu lumpia telur Fungsi biaya (C) untuk menu lumpia telur dapat disusun berdasarkan biaya operasional 
rutin bulanan dan biaya produksi untuk menu lumpia telur.

$$
C=80000+3000 Q
$$

Fungsi harga $(\mathrm{P})$ untuk menu lumpia telur dapat dituliskan sebagai berikut:

$$
P=100 Q-1500
$$

Dengan demikian, diperoleh fungsi penerimaan sebagai berikut:

$$
R=100 Q^{2}-1500 Q
$$

Berdasarkan fungsi penerimaan dan fungsi biaya, fungsi keuntungan dapat dituliskan sebagai berikut:

$\pi=100 Q^{2}-4500 Q-80000$

Derivatif pertama fungsi keuntungan yang disamadengankan 0 menghasilkan titik kritis sebesar 22,5. Hal ini berarti Kedai Ana melakukan penjualan lumpia telur sebanyak 23 porsi dalam jangka waktu sebulan.

Penentuan titik ektrim maksimum atau minimum dilakukan dengan mencari turunan kedua dari fungsi keuntungan. Pada proses ini, diperoleh hasil 200. Hasil derivatif kedua yang lebih besar dari 0 menunjukkan bahwa titik tersebut merupakan titik minimum. Sehingga dapat dinyatakan bahwa Kedai Ana memperoleh kerugian maksimum sebesar Rp-130.600,00 jika tingkat penjualan kopi susu sebanyak 23 porsi dalam waktu sebulan.

d. Analisis keuntungan menu cilok

Fungsi biaya (C) untuk menu cilok dapat disusun berdasarkan biaya operasional rutin bulanan dan biaya produksi untuk menu cilok.

$$
C=80000+3000 Q
$$

Fungsi harga (P) untuk menu cilok dapat dituliskan sebagai berikut:

$$
P=-66,6 Q+11666,6
$$

Dengan demikian, diperoleh fungsi penerimaan sebagai berikut:

$$
R=-66,6 Q^{2}+11666,6 \mathrm{Q}
$$

Berdasarkan fungsi penerimaan dan fungsi biaya, fungsi keuntungan dapat dituliskan sebagai berikut:

$$
\pi=-66,6 Q^{2}+8666,6 Q-80000
$$

Koefisien pada variabel kuadrat fungsi keuntungan bernilai negatif. Hal ini menunjukkan bahwa grafik parabola akan terbuka ke bawah yang berarti keuntungan maksimum dicapai ketika jumlah penjualan bernilai sama dengan titik kritis.

Derivatif pertama fungsi keuntungan yang disama dengankan 0 menghasilkan titik kritis sebesar 65,06. Hal ini berarti Kedai Ana melakukan penjualan cilok sebanyak 65 porsi dalam jangka waktu sebulan.

Penentuan titik ektrim maksimum atau minimum dilakukan dengan mencari turunan kedua dari fungsi keuntungan. Pada proses ini, diperoleh hasil -133,2. Hasil derivatif kedua yang lebih kecil dari 0 menunjukkan bahwa titik tersebut merupakan titik maksimum. Sehingga dapat dinyatakan bahwa Kedai Ana memperoleh keuntungan maksimum sebesar Rp201.944,00 jika tingkat penjualan cilok sebanyak 65 porsi dalam waktu sebulan. Dengan demikian, harga minimal cilok yang perlu ditetapkan oleh Kedai Ana untuk memperoleh keuntungan adalah sebesar Rp7400,00 per porsi.

e. Analisis keuntungan menu gorengan

Fungsi biaya (C) untuk menu gorengan dapat disusun berdasarkan biaya operasional rutin bulanan dan biaya produksi untuk menu Thai tea.

$$
C=80000+3000 Q
$$

Fungsi harga $(\mathrm{P})$ untuk menu gorengan dapat dituliskan sebagai berikut:

$$
P=-100 Q+10000
$$

Dengan demikian, diperoleh fungsi penerimaan sebagai berikut:

$$
R=-100 Q^{2}+10000 Q
$$

Berdasarkan fungsi penerimaan dan fungsi biaya, fungsi keuntungan dapat dituliskan sebagai berikut:

$\pi=-100 Q^{2}+7000 Q-80000$ 
Derivatif pertama fungsi keuntungan yang disamadengankan 0 menghasilkan titik kritis sebesar 35. Hal ini berarti Kedai Ana melakukan penjualan gorengan sebanyak 35 porsi dalam jangka waktu sebulan.

Penentuan titik ektrim maksimum atau minimum dilakukan dengan mencari turunan kedua dari fungsi keuntungan. Pada proses ini, diperoleh hasil -200. Hasil derivatif kedua yang lebih kecil dari 0 menunjukkan bahwa titik tersebut merupakan titik maksimum. Sehingga dapat dinyatakan bahwa Kedai Ana memperoleh keuntungan maksimum sebesar Rp42.500,00 jika tingkat penjualan gorengan sebanyak 35 porsi dalam waktu sebulan. Dengan demikian, harga minimum gorengan yang perlu ditetapkan oleh Kedai Ana untuk memperoleh keuntungan adalah sebesar Rp6.500,00 per porsi.

Berdasarkan analisis yang telah dilakukan, diperoleh hasil sebagai berikut:

a. Penjualan menu jenis Thai tea, cilok dan gorengan di Kedai Ana masing-masing akan mencapai keuntungan maksimum jika terdapat penjualan sebesar 18 porsi, 65 porsi dan 35 porsi per bulan. Jika dibandingkan dengan data penjualan pada bulan November dan Desember 2020, maka Kedai Ana sudah mampu mendapatkan keuntungan maksimum dari penjualan Thai tea dan cilok.

b. Penjualan menu jenis kopi susu, dan lumpia telur di Kedai Ana masing-masing akan mencapai kerugian maksimum jika terdapat penjualan sebesar 12 porsi dan 23 porsi per bulan. Jika dibandingkan dengan data penjualan pada bulan November dan Desember 2020, maka Kedai Ana sudah mampu menghindari kerugian maksimum dari penjualan kopi susu dan lumpia telur.

\section{KESIMPULAN}

Berdasarkan hasil perhitungan dan pembahasan, maka dapat ditarik kesimpulan bahwa analisis keuntungan maksimum dalam prosesnya membutuhkan penyusunan model matematika dari setiap menu atau produk yang ditawarkan. Hasil analisis menyatakan bahwa Kedai Ana belum mencapai keuntungan maksimum karena tidak semua menu yang ditawarkan memiliki hasil turunan kedua yang bernilai negatif.

\section{DAFTAR PUSTAKA}

[1] L. V. Hignasari, "Analisis Keuntungan Maksimum dengan Konsep Turunan pada Industri Percetakan," Jurnal Imiah Vastuwidya Universitas Mahendratta, vol. 1, no. 2, 2018.

[2] B. Asyhar, "Aplikasi Turunan (Derivatif) Dalam Permasalahan Analisis Keuntungan Maksimum," Al-Khwarizmi: Jurnal Pendidikan Matematika dan Ilmu Pengetahuan Alam, vol. 2, no. 1, pp. 1-14, Aug. 2018, doi: 10.24256/jpmipa.v2i1.98.

[3] M. S. Rumetna, T. N. Lina, S. D. Cahya, B. M. Liwe, and M. Kosriyah, "Menghitung Keuntungan Maksimal dari Penjualan Roti Abon Gulung dengan Menggunakan Metode Simpleks dan Software POMQM," Jurnal Jendela Ilmu, vol. 1, no. 1, pp. 6-12, Apr. 2020, doi: 10.34124/ji.v1i1.49.

[4] Z. Nasution, H. Sunandar, I. Lubis, and L. T. Sianturi, "Penerapan Metode Simpleks untuk Menganalisa Persamaan Linier dalam Menghitung Keuntungan Maksimum," Jurnal Riset Komputer (JURIKOM), vol. 3, no. 4, pp. 42-48, 2016.

[5] D. E. Varberg, E. J. Purcell, and S. E. Rigdon, Calculus early transcendentals. Harlow, Essex: Pearson, 2014.

[6] M. N. R. Al-Arif, Matematika Terapan untuk Ekonomi. Bandung: Pustaka Setia, 2013. 